\title{
石黒尚子 学位論文審査要旨
}

$\begin{array}{ccccc}\text { 主査 } & \text { 佐 } & \text { 藤 } & \text { 建 } \\ \text { 副主查 } & \text { 井 } & \text { 藤 } & \text { 雄 } \\ \text { 同 } & \text { 西 } & \text { 連 } & \text { 寺 } & \text { 剛 }\end{array}$

\section{主論文}

Immunohistochemical analysis of a muscle ankyrin-repeat protein, Arpp, in paraffin-embedded tumors: evaluation of Arpp as a tumor marker for rhabdomyosarcoma (パラフィン包埋腫瘍における筋アンキリンリピート蛋白質Arppの免疫組織化学的解析 : 横紋筋 肉腫診断マーカーとしてのArpp評価）

(著者: 石黒尚子、元井亨、尾崎充彦、荒木信人、南崎剛、守山正扸、井藤久雄、吉田春彦) 平成17年6月 Human Pathology 36巻 620頁～625頁 


\section{学 位 論 文 要 旨}

Immunohistochemical analysis of a muscle ankyrin-repeat protein, Arpp, in paraffin-embedded tumors: evaluation of Arpp as a tumor marker for rhabdomyosarcoma （パラフィン包埋腫瘍における筋アンキリンリピート蛋白質Arppの免疫組織化学的解 析 : 横紋筋肉腫診断マーカーとしてのArpp評価）

Arppは、333アミノ酸残基からなる新規アンキリンリピート蛋白質で、正常組織では骨格 筋および心筋を含む横紋筋で特異的に高発現する。横紋筋肉腫は最も発症頻度の高い軟部 肉腫の1つで、その病理組織学的特徵は腫瘍細胞が横紋筋へ分化傾向を持つことである。故 に、本肉腫の診断では、組織学的所見に加え、複数の筋系マーカーを用いた免疫組織化学 染色が行なわれる。過去の検討の結果、Arppが横紋筋肉腫で高頻度に発現することが示唆 され、Arppが横紋筋特異的マーカーとして横紋筋肉腫診断へ応用可能ではないかと推測さ れた。しかしながら、Arppが横紋筋肉腫で特異的に発現するか否かは不明であった。

本研究では、Arppの横紋筋肉腫に対する感度と特異性を明らかにし、Arppが横紋筋肉腫 診断に応用可能であるかを検討した。まず、横紋筋肉腫を含む種々の悪性腫瘍におけるArpp 発現を免疫組織化学的に解析し、横紋筋肉腫に対するArppの感度と特異性を明らかにした。 さらに、既存の筋系マーカーとArppの横紋筋肉腫に対する感度および特異性を比較し、Arpp の診断マーカーとしての有用性を評価した。

\section{方 法}

対象症例として、横紋筋肉腫37例、他の軟部肉腫88例（悪性線維性組織球種27例、脂肪 肉腫10例、平滑䇗肉腫14例、滑膜肉腫11例、悪性末梢神経鞘腫11例、線維肉腫2例、ユーイ ング肉腫5例、類上皮肉腫5例、血管肉腫3例）、癌腫38例（乳癌5例、肝癌4例、肺癌 10 例、 食道癌4例、直腸癌5例、大腸癌5例、胃癌5例）のパラフィン包埋切片を使用した。抗Arpp ポリクローナル抗体は全長Arpp蛋白質を抗原として作製した。対象症例におけるArpp発現 は、抗Arppポリクローナル抗体を用い、ストレプトアビジン・ビオチン法による免疫組織 化学染色で検討した。また、横紋筋肉腫の凍結材料3例を用い、ウエスタンブロット法によ るArpp発現解析を行なった。Arppと既存筋系マーカー(ミオグロビン、MyoD、myogenin、デ スミン、筋特異的アクチン)の感度および特異性の比較は、免疫組織化学染色により横紋筋 肉腫および他の軟部肉腫での陽性率を比較することにより評価した。 


\section{結 果}

免疫組織化学染色の結果、Arppは横紋筋肉腫37例中33例 (89.2\%) で陽性であった。Arpp 蛋白質は腫瘍細胞の細胞質で検出され、3種類ある横紋筋肉腫組織亜型の全てで陽性であつ た。Arpp陽性例33例のうち、18例は陽性細胞率が 10\%～50\%の散在性分布を示し、4例は50\% 以上の強陽性、11例は1\%〜10\%の弱陽性であった。また、Arpp陽性率は腫瘍細胞の䇗分化度 に比例しており、筋分化度の高い大型腫瘍細胞での陽性率は高く、筋分化度の低い小型腫 瘍細胞での陽性率は低かった。横紋筋肉腫の凍結材料を用いたウエスタンブロット解析で は、解析を行った横紋筋肉腫3例全例でArpp蛋白質が検出され、免疫組織化学染色の結果が 裏付けられた。

一方、横紋筋肉腫以外の悪性腫瘍126例におけるArpp陽性率は6.3\%（8/126）であった。 既存筋系マーカーとの比較では、横紋筋肉腫におけるArpp陽性率 (89.2\%) はミオグロビン (59.5\%)より高く、myogenin (88.2\%), MyoD (80.6\%)，デスミン $(89.2 \%)$ ，筋特異的アクチ ン (83.8\%) とほぼ同程度であった。また、腫瘍細胞の筋分化度の高い横紋筋肉腫症例では Arpp陽性率がmyogenin陽性率より高かった。一方、横紋筋肉腫以外の軟部肉腫におけるArpp 陽性率 (9.1\%) は、ミオグロビン (4.5\%)、myogenin (4.5\%)、MyoD (3.4\%) を含む横紋筋特異的 マーカーより高かったが、筋特異的アクチン (18.2\%)、デスミン (13.6\%)を含む横紋筋非特 異的マーカーより低かった。

\section{考 察}

横紋筋肉腫において、Arppは89\%と高い陽性率を示し、その発現は腫瘍細胞の筋分化度と 比例した。一方、横紋筋肉腫以外の悪性腫瘍におけるArpp陽性率は6\%と低く、Arppは横紋 筋肉腫に対し高い感度と特異性を持つことが示唆された。

$\operatorname{Arpp}$ の感度・特異性を既存筋系マーカーと比較したところ、Arppの横紋筋肉腫に対する 感度は既存の筋系マーカーと比較しても高かった。一方、横紋筋肉腫に対する特異性は横 紋筋特異的マーカーより低いものの、横紋筋非特異的マーカーより高かった。したがって、 Arppの感度と特異性は既存の筋系マーカーと比較しても有用であると推察された。

\section{結 論}

Arppは横紋筋肉腫に対し高い感度と特異性を有し、さらに既存筋系マーカーと比較して もその感度と特異性は有用であった。したがって、Arppは新規横紋筋特異的マーカーとし て、横紋筋肉腫の診断に応用可能であると期待された。 